\title{
Entrepreneurial Orientation and Performance of Selected SMEs in Southeast, Nigeria
}

\author{
Ifeanyi E. NuelOkoli, Kanayo Chike Nwosu, and Miracle Ejike Okechukwu
}

\section{ABSTRACT}

This study examines the effect of entrepreneurial orientation on performance of selected small and medium scale enterprises (SMEs) in Southeast Nigeria. The problems that led to this study include, inadequate access to finance, poor infrastructure, inconsistency with government policy, poor support (business development work), inadequate sales, too many taxes and obsolete technologies leading to massive failures. It has not been found that the epileptic growth of SMEs in Southeast Nigeria is not only due to the problems but also from the entrepreneurial orientation. The survey research method was employed in this study and the study relied on secondary and primary data. The population of this study was drawn from SMEs in the five states in the Southeast Nigeria. The study was done using three hundred and sixty six small and medium enterprises (SMEs). Complete enumeration was adopted. Simple regression analysis was used to analysis the hypotheses. The study revealed that there is a significant positive relationship between proactiveness, innovativeness and risk taking on performance of SMEs in Southeast Nigeria. The study concluded that entrepreneurial-oriented firms tend to lead the industry with innovations, performing things in a better approach to satisfy customers and give the firm a better leverage. The study recommends that SMEs owners and managers should be committed to process and radical innovation in their dealings so as to increase and expand their customer base.

Keywords: Entrepreneurial Orientation, Innovativeness, Pro-activeness, Risk-taking, Small and Medium Enterprises, Firm Performance.
Submitted : June 20,2021

Published : July 15, 2021

ISSN: $2507-1076$

DOI: $10.24018 / \mathrm{ejbmr} .2021 .6 .4 .946$

Okoli Ifeanyi E. Nuel *

(e-mail: ie.okoli@unizik.edu.ng)

Nwosu Kanayo Chike

Miracle Ejike Okechukwu

*Corresponding Author

\section{INTRODUCTION}

In spite of the huge natural and human resources, Nigeria suffers some problems. Until the late 1960s, the country was a free food producer and a major exporter of agricultural products. Since the early 1970 s, when oil became a major source of income for foreign exchange and an avenue to gain Gross Domestic Product (GDP), other sectors of the economy fell behind and while revenues of crude oil have not been managed effectively to stimulate the desired levels of growth and sustainable economic development. To solve the challenges in the economy, various governments have launched various programs. One of the programs was the introduction of the Structural Adjustment Program (SAP), 1986 with the aim of reorganizing and expanding economic resources with the aim of reducing over reliance on the oil and gas sector. The over reliance on the single product (oil) operating on allocation system has made the Nigerian economy at risk to changes in the world prices of oil and its products. Given this, in 2006, the government ordered that entrepreneurship education should be integrated into all programs proposed in our tertiary learning institutions as a required course. Likewise, at the $53^{\text {rd }}$ meeting of the National Council of Education (NCE), gave the higher education sector the opportunity to start developing the suitable training curriculum for an effective and efficient system. It was believed that this would generate a lots of entrepreneurs with the correct integrity and skills, transformation and entrepreneurship, allowing people to be job creators rather than job seekers and thus address the challenges of joblessness from graduates in the country and thus generate job opening for the Nigerian youth to enlarge the economy of Nigeria [1]-[3].

As small and medium-sized enterprises (SMEs), they play a critical role in the economic growth and development of the world's emerging, both developing and developed economies. The development of the SME sector is a way to help the government achieve its goal of enhancing entrepreneurship as a vehicle to accelerate industrialization, solving the challenges of unemployment and general economic growth. The involvement of the SME sector to the economy of Nigeria demonstrates that it is a strategic mechanism for economic growth and development. Micro, Small and Medium Enterprises (MSMEs) employ approximately $84.02 \%$ of the total workforce, constitute $96 \%$ of businesses in Nigeria and contribute $48.47 \%$ to the Gross Domestic Product (GDP) of the nation [4].

SMEs are placed to play an important role in the country's economic development and transformation activity in accordance with the mantra of change, and the economic 
expansion goal of the Federal Government of Nigeria. The main barrier hindering the growth of SMEs in Nigeria are outdated technologies, multiple taxes, inaccessible markets, poor support (business development services), inconsistency in government policies, inadequate infrastructural facilities, and difficulty in accessing finance [4]. The African Development Bank Group [5] remarked that the Nigerian business environment is fraught with market collapse and this has led to underfunding of SME sector, which is key for employment and economic expansion and this highlights the need to provide financial assistance to small and medium sized companies through reputable local banks.

There is agreement among some scholars that entrepreneurial orientation (EO) leads to the success and profitability of firms [6]-[9]. Entrepreneurial orientation (EO) is a decision-making exercise and operation used to take measure in a business manner at the organizational level [10]. EO as an idea in the field of entrepreneurship is seen as a medium towards achieving the profitability, success, and growth of SMEs. There are three dimensions of EO namely, innovation, risk taking and pro-activeness. Updating the dimensions from EO to five, include autonomy, competitive aggressiveness, risk-taking, pro-activeness and capacity for innovation and advancement of the genuine plan contemplated by Miller [11] are attributed to Covin \& Slevin [12], Lumpkin \& Dess [10].

Several studies have revealed that organizations that exhibit a more entrepreneurial orientation function better [13]. However, Smart \& Conant [14] report no significant entrepreneurial orientation and organizational performance. Hart [15] argues that the manner in which a company's business strategy is crafted can even lead to poor performance under certain circumstances. Due to the encouragement of business activity, the country has witnessed unstable growth among numerous privately owned companies and economic development. Therefore, this study aimed to examine the effect of entrepreneurial orientation variables on SMEs performance.

\section{A. Statement of the Problem}

The birth, growth and sustainability of small and mediumsized enterprises are essential for achieving economic growth and development of countries. In spite of this, the fact is that the activities of SMEs are affected by problems such as inaccessibility of finance, infrastructural inadequacy, inconsistent policies of government, limited access to market, multiple taxation and outdated technologies, leading to a high failure rate. The slow growth of SMEs in Enugu cannot be ascribed mainly to the aforementioned challenges, but mainly to limited EO. In light of the above framework, many efforts have been made in recent years to increase small and medium-sized enterprises in the Nigerian economy. First, the Small and Medium Enterprise Development Agency of Nigeria (SMEDAN) was established as the only agency responsible for the promotion and development of this sector. In addition, the National Business Development Program (NEDEP) was implemented. Others were the creation of the National and State Councils of MSMEs, the Youth Enterprise with Innovation in Nigeria (YouWiN), the revised National MSMEs Policy and other access to finance from the Central Bank of Nigeria and other development banks [4].
Sadly, all these efforts did not yield the best performance for the SME sector. Akeredolu[16] emphasizes that the control rights of Nigerian private entrepreneurs are often denied; and business stagnation among African entrepreneurs in manufacturing; corroborated by the low value added of African SMEs shares and the shortage of companies in the categories of 20 to 49 employees and 50 or more. In the event of a failure, SMEs design and execute strategies to survive and thrive in a changing business environment. Entrepreneurial orientation (EO) is therefore an important idea in the adoption of strategy in the concept of entrepreneurship and strategic management, which has been identified in earlier studies as affecting SMEs operations. As a result, EO is expected to be adopted to boost the performance of SMEs, demonstrated by their resources. Although many factors can affect the performance of SMEs, thus the roles of the EO have not been fully utilized. Most of the studies performed on the effect of EO on SME performance have focused on developed countries. While a number of studies have examined the EO - performance relationship in Africa, there is a lack of research that has examined the relationship with EO performance in the context of small and medium-sized enterprises in Nigeria, with the exception of a few studies. This study expands the literature on the EO-performance relationship by focusing on the effect of entrepreneurial orientation on performance of selected small and medium scale enterprises (SMEs) in Southeast Nigeria.

\section{REVIEW OF RELATED LITERATURE}

\section{A. Entrepreneurial Orientation}

Entrepreneurial orientation (EO) is a critical factor to the success of organizations. Entrepreneurial orientation is envisioned as a process and decision-making activity used by entrepreneurs that leads to new entrance and aid for business ventures [17], [18]. Entrepreneurial orientation has been described as consisting of three dimensions: innovativeness, risk taking, and pro-activeness. Miller [19] argues that these three components of entrepreneurship constitute a basic onedimensional strategic orientation. Innovativeness requires looking for creative or unusual solutions to problems and needs. This area includes product development, establishing of new markets and innovative systems and technology for processing operations. The risk-taking dimension refers to the readiness of the management to invest large amounts of resources and opportunities despite the uncertainty. Previous EO of firms involves pro-activeness in the search for new business opportunities, risk-taking, and innovativeness [18].

\section{B. Dimensions of Entrepreneurial Orientation}

\section{Innovativeness}

Innovation is seen as the development and use of new concepts or practices in organizations to demonstrate in a product, service, technology, or design process [20]. The organization supports a new strategy based on the knowledge of market players [21]. Innovativeness is the objective to aid new plan and to support change [22]. It encompasses the creation and adoption of technologies and internal activities [23]. Keh, Nguyen \& Ng [24] opined that innovativeness as 
the tendency of organizations to get involved in inventive operations or to experiment with new ideas, which can lead to the introduction of new production methods or new products or services to be brought to present or new markets. Furthermore, innovativeness refers to a concerted effort to gain access and introduce innovative technology systems with robust operations. It sometimes involves spending on research and development (R\&D) activities to develop a new product or service in a new market. Innovative firms bring to the fore new ways and take in a huge number of skilled workers. Innovation is reflected in their approach to finding creative, exceptional or innovative solutions to the problems they encounter and meeting production needs. These solutions are available in the form of new technology and systems, as well as new products and services. Most SMEs in developing countries do not have the financial capability to plough money into research and development because of their unhealthy economic potential.

\section{Pro-activeness}

Pro-activeness is the prospect that requires the opportunity of an entrepreneur. It is a state of anticipation that reflects and makes strategic changes in the market as well as creating new processes and products [25]. Pro-activeness is seen as an entrepreneurial preparedness to control rivalries via dynamic movements, such as introducing a new product or service in front of rivalries and taking action in expectation of the future to institute change and improve the environment [24]. Looking for customers who are expecting something new, regular product updates and a better understanding of what they want, as well as, improved products is becoming the focal point of competition for numerous organizations [26]. Pro-activeness is related to striving for the first leading advantages by investing efforts in environmental scanning in order to identify new trends and keep up to date with the competition [27]. Evidence suggests that pro-activity is related to the numerous of innovations generated; hence, the greater the pro-activity of the firm, the greater the inclination to favour innovation generation [28].

Pro-active organizations try to stay ahead of others with the aid of new technology, marketing new product or service. Pro-active firms grab opportunities and concentrate on new product or service creation, utilizing trends to suit future needs of customers and predict changes in demand or emerging problems that lead to new business opportunities [29]. The initial mobility benefit is achieved when the operating firms first enters a new market and establishes identity, implements a design process or uses new workflow technologies in the firm thus having a leverage over their rivalries [30], [31]. In general, pro-activeness is the desire to predict and respond to the needs of the market and future opportunities [32], [33].

\section{Risk Taking}

Risk taking is concern with the tendency and readiness to devote reasonable resources to taking advantage of chances or engaging in business strategies where the result may not be fully known. Pérez-Luño, et al. [34] opined that risk taking refer to the risk factor reflected in decision making assets as well as alternative of products and markets. The practice of threats undermines export barriers and paves the way for the pursuit of new opportunities in foreign markets. Rauch et al.
[22] found that the risk taking has a performance-related effect, even if it is less than other parts of the EO. The relationship between risk taking and performance is not too strong than the one between pro-activeness and innovativeness [22]. Risk taking is regarded as an independent variable and is connected to other part of EO [35]. Pérez-Luño et al. [34] stated that risk-taking is positively related to the number of innovations created by the firm and that the greater the firm's risk-taking capacity, the greater the tendency to prefer creating innovation.

Risk-taking indicates a firm's loyalty to huge cost projects and taking bold and rapid actions to low losses. It also requires investing heavily in new technologies as well as selling new products or services in new markets [29]. Risk taking orientation means that companies should take risks to achieve higher financial returns by incurring higher cost, investing more amounts of corporate resources, introducing new products into new markets, and investing in unexplored technologies and opportunities. A risk taking firm would be willing to devote huge resources to opportunities that are likely of costly failure [36].

\section{Entrepreneurial Orientation and Performance of SMEs}

\section{Pro-activeness and Sales Growth}

Pro-activeness is the opportunity and forward-looking dimensions which includes presentation of new products/services and acting towards future demand. This statement includes a company's willingness to venture the export market. Pro-activeness can also be referred to as a wide variation of activities to include recognizing opportunities and market trends, evaluating the strengths and weaknesses of opportunities, and setting up teams that are able to take advantage of them [18].

Wisner [37] posits that the indicators of pro-activeness of SMEs includes, building greater trust in customers, identifying and participating in new products, enabling team members to collaborate always, create compatible communication and involve all members of the supply chain in the company's product / service marketing plans, which if implemented correctly will lead to high performance of the organization. Mentzer, Stank, \& Esper [38] state that SME represents a proactive-oriented approach based on a close relationship with the company's business and marketing strategy, process, and expertise. The supplier management and customer interaction strategy, which are consistent with the proactive process, were found to have a positive impact on organizational performance.

Green, McGaughey, \& Casey [39] found that market orientation is positively and significantly related to proactive strategies of SMEs that in turn lead to higher organizational performance. This brings a number of business marketing strategies that drive sales forward. Mentzer [40] emphasizes that proactive orientation plays an important role in SME implementation and overall performance management. Tukamuhabwa, Eyaa \& Derek [41] further identified a positive association between pro-activeness and SME management strategy together with organizational performance.

Salvador, Forza, Rungtusanatham, \& Choi [42] argue that when firms are proactively oriented through interaction with suppliers and customers about materials flow and quality 
issues, they achieve better scheduling function with regard to speed and time delivery. Suboptimal organizational performance may be due to a weak market and proactive orientation. Effective SMEs include market orientation and cost saving, which enhances the company's financial performance. According to Juttner, Martin, \& Godsell [43], management and customer relationships, that are part of a proactive orientation, affect organizational performance in terms of short-term deadlines, costs and short life span. Therefore, a high level of customer service system will have a significant positive effect on customer performance.

Zelbst, Green, Sower \& Baker [44] argue that innovation orientation performance focuses on the ability of the SME to satisfy the needs of the ultimate customers which leads to high organization performance. Miguel, Augusto, \& Manuel [45] argue that the strong need for proactive workers who also have the ability to manage themselves is due to the challenging nature of the work itself. This attitude leads to high performance within the organization itself. Proactive investments in security are related with longer gaps before subsequent breaks than reactive investments. Furthermore, external control pressures can trigger learning and organizational processing. It is clear that the relationship between external pressures and proactive investment increases the positive impact of investment.

The implication of this view is that proactive investment, made voluntarily, has the greatest impact on safety performance where managers and policymakers should pay attention to the procedures and policies that affect financing decisions. The implications for proactive and responsive learning with external regulatory pressure can be generalized to other industries. In various areas of organizational performance, learning has been found to be important for growth. Organizational learning, therefore, describes ways members gain the knowledge and skills needed to attain greater performance, which has a tradition of scrutinizing the decisions surrounding investing in quality and volume and productivity [46].

\section{Innovativeness and Profitability}

Innovation is a critical factor in ensuring the benefits of competition through long-term planning and commitment. Joseph Schumpeter highlighted the importance of innovation as a key factor in his economic growth and development in his Theory of Economic Development (1934). According to Casals [47], the globalization of markets and international competition is forcing more and more small and mediumsized companies to look for flexible, transformative and imaginative ways to survive. This provides the foundation for the SME to create something new to survive. Moreover, innovation is a key factor in modern society based on knowledge for SME operations, although there is little evidence of this in terms of emerging economies. But SMEs need to be constantly evolving to reduce production costs, delivery costs, as well as service manufacturing expertise, product delivery relationships among other business processes.

SMEs that have adjusted flexible production process and competitive costs and prices have been able to gain greater market share [48]. This highlights the essence of innovation in promoting long-term loyalty and value to customers.
Rothwell \& Zegveld[49] emphasizes that SMEs demonstrate a behavioural strategy that allows them to innovate more than bigger firms; for example, it is believed that SMEs can respond quickly to external threats or opportunities; they have internal communication skills and show a kind of relationship management. SME, On the other hand, SMEs are thought to lack the technology that enables large companies to expand the threat and portfolio of new products and pay long-term $\mathrm{R} \& \mathrm{D}$. So, it may come as no surprise that innovation is not associated with big companies [49].

\section{Risk-taking and Market Share}

Risk-taking centred on the readiness of entrepreneurs to take part in premeditated business risk which in the end leads to high business performance. Lumpkin \& Dess [50] identify venturing into the unknown as a definition for risk taking which leads to great firm performance. This is because it provides SMEs the foundation to grow and integrate into new products without having to worry about its consequences. Studies have found that SMEs that take risks perform better in terms of profitability than those who do not. Such firms are also expected to have better performance and a higher level of risk propensity. Leko-Simi \& Horvat [51] viewed risktaking as the desire to own or avoid risks and is considered as a human trait. A positive association between risk-taking and critical decision-making by people is likely to be translated into organizations by the senior management team, hence high performance of the SMEs [52].

Risk-taking is vital to aid both innovativeness and proactiveness in SMEs and fosters organizational creativity [19], [53]. Under unforeseen circumstances, risk taking is positively associated with development of new products. It is also evident that risk-taking in SME encourages and reveals behaviours that lead to process enhancements, new products or services, and innovative practices leading to high performing SMEs. Gupta \& Govindarajan [54] showed that risk-taking has a significant impact on successful implementation of an SME's plans that aims for higher performance. Effective implementation means that a firm will have few obstacles in developing its system depending on its resources and competence. Therefore, risk-taking can play an important function in ameliorating functional barriers through the development and implementation of an effective strategy. The desire of managers to take risks should enable SME capabilities to adapt to the needs of the market and thus face fewer barriers.

Creating strategic business unit (SBU) is a critical quality that will contribute to the performance of the SMEs. The purpose of the strategic business unit is to provide direction, guidance and help streamline the overall innovative strategy to the entire firm's objectives. Engaging in collaborative strategic sourcing is another risk-taking characteristic that will lead to the efficiency and effectiveness of the firm. Strategic sourcing in the risk-taking process is a key cornerstone of successful SME performance. The need for risk taking increases now more than the problem, of longterm and short-term financing issues. Thus, determining the existence of a risk management strategy is not enough as managers need to use risk management practices to deal with the transfer of key issues facing small and medium-sized companies today. The use of corporate risk as a business 
strategy can be used to help managers build opportunities. SMEs should apply to existing risk activities, putting the risk knowledge at work, across all of the different corporate risks such as strategic risks, operational risks, financial risks and regulatory compliance risks.

\section{Conceptual Framework}

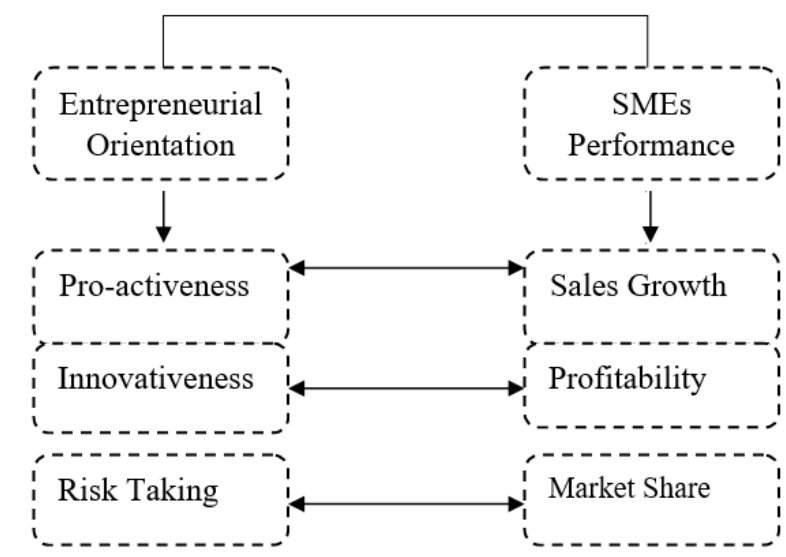

Fig. 1. Conceptualization of Entrepreneurial Orientation on Performance Source: Researcher, (2021).

\section{E. Empirical Review}

Numerous studies have examined the effect of entrepreneurial orientation on performance of SMEs with mixed results:

Ibrahim \& Mahmood [55] examined the impact of entrepreneurial orientation and competitive advantage on SMEs performance in Nigeria. Additionally, the research examined whether competitive advantage mediates the relationship between EO and performance of SMEs. The research revealed that there is a positive and significant relationship between EO and SMEs performance. In the same vein, the finding showed a positive and significant relationship between competitive advantage and SMEs performance. Furthermore, the research affirmed that competitive advantage mediates the relationship between EO and the performance of SMEs in Nigeria.

Arisi-Nwugballa, Elom \& Onyeizugbe [56] examined the impact of the dimensions of EO on the performance of Micro, Small and Medium Enterprises (MSMEs) in Ebonyi State. The research found that the three dimensions of EO were significant to one measure of the performance of MSMEs. Furthermore, the research affirmed that competitive aggressiveness is significantly related to both customer and product performance. Similarly, innovativeness and proactiveness had a significant relationship with customer performance. Risk-taking and autonomy were not significantly associated with any of the performance measures, indicating that they are not relevant to the performance of MSMEs.

Kumarpeli \& Semasinghe [57] investigated the relationship between EO and SMEs growth in Sri Lanka using a descriptive research design and Analysis of Variance (ANOVA) methodologies. The study examined the relationship between the three dimensions of EO innovativeness, risk-taking, and pro-activeness on the growth of SMEs. The research revealed that EO has an effect on SMEs growth. Also, the findings showed that innovativeness and risk-taking have a positive effect on SMEs growth. Nevertheless, the findings showed that pro-activeness has no significant effect on SMEs growth.

Baker, Mahmood \& Ismail [58] examined the relationship between EO, strategic improvisation and performance of SMEs in Malaysia. Data were collected through mail questionnaires and the results indicated that there is a significant relationship between EO and the performance of SMEs. Okeyo, Gathungu \& K'Obonyo [59] examined the association between EO, business development services, business environment and firm's performance. The findings also revealed that business development services play a mediating role in the EO and performance relationship and that external environment moderates this relationship. Nevertheless, the results showed no role of internal environment in the EO-firm's performance relationship.

Amin [60] examined the effect of EO and learning orientation on SMEs performance in Malaysia. The findings depict that EO dimensions (innovativeness, pro-activeness, and risk-taking) and learning orientation significantly related to performance of SMEs. Kraus, Rigtering, Hughes, \& Hosman[61] adopted a survey research design to investigate the effect of EO on SMEs performance in Netherland during the global economic and financial crisis. It was evident from the finding that during the economic and financial crisis, proactive firm's behaviour contributed positively to SMEs performance. The findings also indicated that innovative SMEs performed better in turbulent environments. The study concluded that innovative SMEs should reduce their risk levels and take action to avoid uncertain projects.

Using descriptive research design on a sample of 1141 SMEs of which 740 were micro enterprises, Civelek, Rahman \& Kozubikova [62] examined the differences of gender, education level of entrepreneurs and enterprises' age as it concerned EO in the segment of microenterprises in the Czech Republic. The analysis consist all the dimensions of EO such as competitive aggressiveness, autonomy, proactiveness, innovativeness, and risk-taking. The findings revealed that micro-entrepreneurs with university education were more innovative and autonomous compared to microentrepreneurs with a lower level of education. The results also showed that younger micro firms are more proactive, innovative, and willing to venture into risks than the older micro firms. However, the results did not show any significant differences between men and women in relation to all dimensions of EO.

\section{METHODS}

The research design used for this study is descriptive survey design. This is because this study seeks to elicit data for analysis through the use of a questionnaire. The population of the study consists of 366 SMEs. Three hundred and sixty six (366) SMEs from Anambra State, Enugu State, Imo State, Abia State and Ebonyi State formed the population of the study. Complete enumeration was adopted and so there was no need for sampling as all the selected SMEs were used. A five-point Likert structured questionnaire was used in collecting data from respondents. The arrangement of the codes are as follows: Strongly Agree (5), Agree (4), Undecided (3), Disagree (2) and Strongly Disagree (1). Face 
and content validity were used to validate the research instrument. Reliability analysis run with Cronbach Alpha indicates high internal consistency (see table 1 below). The alpha coefficients showed that pro-activeness, innovativeness, risk taking, market share, sales growth, and profitability scored $0.984,0.983,0.973,0.988,0.993$, and 0.988 , respectively.

\begin{tabular}{ccc}
\multicolumn{3}{c}{ TABLE I: RELIABILITY ANALYSIS } \\
\hline Variable & Number of items & $\begin{array}{c}\text { Cronbach's } \\
\text { Alpha }\end{array}$ \\
\hline Pro-activeness & 5 & 0.984 \\
Innovativeness & 4 & 0.983 \\
Risk Taking & 5 & 0.973 \\
Market Share & 4 & 0.988 \\
Sales Growth & 5 & 0.993 \\
Profitability & 4 & 0.988 \\
\hline
\end{tabular}

The statistical tools used in the demographic data presentation include percentages and frequencies to examine the respondent's bio data. The simple regression analysis was used to test the hypotheses.

\section{STAtistiCAl ANAlysis AND TEST RESUlts}

\section{A. Demographic Analysis}

The research showed that $21(5.7 \%)$ of the SMEs had existed in less than one years. $117(32.0 \%), 72(19.7 \%), 81$ $(22.1 \%), 75(20.5 \%)$ of the SMEs had been different lines of business for 1-3 years, 4-6 years, 7-10 years, and 10 years and above, respectively. In addition, SMEs who render services outnumbered the manufacturing firms. For example, 108 $(29.5 \%)$ of the SMEs engaged in manufacturing whereas 258 (70.5) of them provide various degrees of services. The result of the demographic analysis showed that the target SMEs had the capacity to participate in the survey.

The three hypotheses were tested using simple linear regression tool.

\section{B. Hypothesis One}

$\mathrm{Ho}_{1}$ : Pro-activeness does not significantly influence sales growth of SMEs in Southeast Nigeria.

TABLE II: ThE EXTENT To Which PRO-ACTIVENESS INFLUENCE SALES GROWTH OF SMES

\begin{tabular}{|c|c|c|c|c|c|}
\hline \multicolumn{6}{|c|}{ GROWTH OF SMES } \\
\hline Variable & Beta & $\mathrm{t}$ value & $\begin{array}{c}\mathrm{R} \\
\text { Square }\end{array}$ & F value & Sig. \\
\hline (Constant) & & -5.906 & & & .000 \\
\hline Pro-activeness & .984 & 104.346 & .968 & 10888.019 & .000 \\
\hline
\end{tabular}

The result determined a positive, statistical relationship between pro-activeness and sales growth of SMEs in Southeast, Nigeria (Beta $=0.98, \mathrm{t}=104.35, \mathrm{r}^{2}=.968, \mathrm{~F}=$ $10888.019, \mathrm{p}<.01)$. Thus, the null hypothesis was rejected. The result showed that $97 \%$ change in the sales growth of SMEs was associated with change in the pro-activeness of the SME in question. This shows that pro-activeness of the SME exerts high level of influence on sales growth of SMEs in Southeast, Nigeria. The result implies that pro-activeness was an important predictor of sales growth of SMEs in Southeast, Nigeria. Changes in pro-active tendencies of SMEs tend to influence changes in sales growth of SME. This means that the pro-active a firm is, the higher its sales grows and vice

\section{versa.}

\section{Hypothesis Two:}

$\mathrm{Ho}_{2}$ : Innovativeness does not significantly influence profitability of SMEs in Southeast.

TABLE III: THE EXTENT TO WHICH INNOVATIVENESS INFLUENCE

\begin{tabular}{llllll}
\multicolumn{5}{c}{ PROFITABILITY OF SMES } \\
\hline Variable & Beta & t value & $\begin{array}{l}\text { R } \\
\text { Square }\end{array}$ & F value & Sig. \\
& & & Squ & \\
\hline (Constant) & & 8.979 & & & .000 \\
Innovativeness & .532 & 11.998 & .283 & 143.954 & .000 \\
\hline \multicolumn{7}{l}{ Dependent Variable: Profitability. }
\end{tabular}

The research ascertained that innovativeness significantly relate with profitability of SMEs in Southeast, Nigeria (Beta $\left.=0.53, \mathrm{t}=11.998, \mathrm{r}^{2}=.283, \mathrm{~F}=143.954, \mathrm{p}<.01\right)$. Hence, the null hypothesis was rejected. The result also showed that $28 \%$ change in a firm's profitability was associated with change in the firm's innovativeness. It implies that innovativeness of a SME exerts low level of influence on the firm's profitability. The research indicated that innovativeness of an SME slightly predicts the profitability of the firm. In other word, changes in a firm's innovativeness had a little influence on the firm's profitability. Nevertheless, innovative SME tend to experience greater profitability than non-innovative ones.

\section{Hypothesis Three:}

$\mathrm{Ho}_{3}$ : There is no significant relationship between risk taking and market share of SMEs in Southeast Nigeria.

TABLE IV: THE EXTENT TO WHICH RISK TAKING INFLUENCE MARKET SHARE OF SMES

\begin{tabular}{cccccc}
\multicolumn{5}{c}{ SHARE OF SMES } \\
\hline Variable & Beta & t value & $\begin{array}{c}\text { R } \\
\text { Square }\end{array}$ & F value & \multirow{2}{*}{ Sig. } \\
\hline (Constant) & & 1.207 & & & .228 \\
Risk Taking & .980 & 94.388 & .961 & 8909.048 & .000 \\
\hline Dependent Variable: Market Share.
\end{tabular}

The result showed that risk taking significantly influenced market share of SMEs in Southeast, Nigeria (Beta $=0.98, \mathrm{t}=$ $\left.94.388, \mathrm{r}^{2}=.961, \mathrm{~F}=8909.048, \mathrm{p}<.01\right)$. Thus, the null hypothesis was rejected. It was also established that $96 \%$ change in market share of SMEs in Southeast, Nigeria was related to change in the firm's risk taking. Thus, risk taking exerts high degree of influence on market share of SMEs. The research has established that risk taking was a key predictor of market share of SMEs. SMEs which take risk tend to grow market share more those who avoid risks.

\section{DisCUSSION OF FINDINGS, CONCLUSION AND RECOMMENDATIONS}

The first research objective was to ascertain the extent to which pro-activeness influence sales growth of SMEs in Southeast Nigeria. The result determined a positive, statistical relationship between pro-activeness and sales growth of SMEs in Southeast, Nigeria. The influence of pro-activeness on performance of Small and Medium Enterprises (MSMEs) was determined in previous studies [56], [57], [60], [61]. In the study of MSMEs in Ebonyi State, Arisi-Nwugballa, et al. [56] found that pro-activeness had a significant correlation with customer performance. Amin [60] investigated the 
impact of EO and learning orientation on SMEs performance in Malaysia. It was found that pro-activeness had a significant relationship with the performance of SMEs. Kraus et al. [61] examined the impact of EO on the performance of SMEs in the Netherland during the global economic and financial crisis. The result showed that proactive firm behaviour contributed positively to the performance of SMEs. On the contrary, pro-activeness did not significantly relate to the growth of SMEs in some surveys. For example, Kumarpeli \& Semasinghe [57] ascertained that pro-activeness had no significant impact on the growth of SMEs in Sri Lanka.

The second research objective was to determine the extent to which innovativeness influence profitability of SMEs in Southeast, Nigeria. The research ascertained that innovativeness significantly related with profitability of SMEs in Southeast, Nigeria. This finding was supported by Arisi-Nwugballa et al. [56], Kumarpeli \& Semasinghe[57], Amin [60], and Kraus, Rigtering, et al [61]. Arisi-Nwugballa et al. [56] found that innovativeness significantly correlated with customer performance. Kumarpeli \& Semasinghe[57] determined that innovativeness had a positive impact on the growth of SMEs. Amin [60] revealed that innovativeness had a significant relationship with the performance of SMEs. Kraus et al. [61] established that innovative SMEs performed better in turbulent environments. Thus, innovativeness is a key predictor of business profitability.

The third research objective was to examine the extent of relationship between risk taking and market share of SMEs in Southeast, Nigeria. The result showed a significant, statistical relationship between risk taking and market share of SMEs in Southeast, Nigeria. The result is consistent those of Kumarpeli \& Semasinghe[57], and Amin [60]. Kumarpeli \& Semasinghe [57] examined the relationship between EO and growth of SMEs in Sri Lanka. The results indicated that risktaking had a positive impact on the growth of SMEs. In a study of electronic and electrical sector and beverage industries in Malaysia, Amin [60] found that risk-taking had a significant relationship with the performance of SMEs. The result contradicted with that of Arisi-Nwugballa et al. [56]. In a study of Micro, Small and Medium Enterprises (MSMEs) in Ebonyi, Arisi-Nwugballa et al. [56] ascertained that risktaking had no significant correlation with the performance of MSMEs.

These findings show that SMEs in developing countries such as Nigeria can accelerate their development, seek opportunities for new technologies, new products, niche markets, and financial markets by entering the foreign market. The study concludes that, an entrepreneurial orientation was positively associated with performance indicators. Entrepreneurial-oriented firms have a tendency to be an industry leader with innovations, by doing things in better ways that better satisfy customers and give the company a competitive edge.

In line with the findings and conclusion, the study recommends that:

1. Small and medium enterprises should be consistent in being pro-active in all business endeavours. This will enable them take first mover advantage and become strong market competitors.

2. SMEs should be committed to process and radical innovation in their dealings so as to increase and expand their customer base.

3. SMEs should take calculated risks in order that they will grab huge market potentials.

\section{REFERENCE}

[1] Adamu, L.E. (2015). Repositioning Nigeria University Education for Economic Development through Entrepreneurship Education, Journal of Education and Practice; 6(25), 34-40.

[2] Mukhtar, S. (2013). Insuring the uninsurable for poverty alleviation in Nigeria: What micro-insurance can do?" Mediterranean Journal of Social Sciences; 4(2), 373-380.

[3] Agbeze, C. (2012). Entrepreneurship: The need to create wealth why not now. Ohafia Today; 2(32), 7-12.

[4] SMEDAN, (2013). SMEDAN and National Bureau of Statistics collaborative survey: Selected findings. Abuja: Small and Medium Enterprises Development Agency of Nigeria.

[5] African Development Bank Group (2013). AfDB and Nigeria: Leveraging partnership for economic transformation and inclusive growth. Tunis-Belvedere: Communication and External Relations Department (CERD).

[6] Islam, A., Khan, M.A., Obaidullah. A.Z.M. \& Alam. M.S. (2011). Effect of entrepreneur and firm characteristics on the business success of Small and Medium Enterprises in Bangladesh. International Journal of Business and Management; 6(3), 289-299.

[7] Hui, Li Y., Wen. H.J. \& Tien. T.M. (2009). Entrepreneurial orientation and Firm performance: The role of Knowledge Creation Process. Industrial Marketing Management; 38:440-449.

[8] Quince, T. \& Whittaker, H. (2003). Entrepreneurial orientation and entrepreneurs' intentions and objectives. ESRC Centre for Business Research, Working Paper; 271.

[9] Lim, S. (2008). Entrepreneurial orientation and the performance of service business; 2008. Accessed on 5th May 2021 Retrieved from http://www.decisionscience.org/Proceedings/DS12008/docs/3929586.pdf.

[10] Lumpkin, G.T., \& Dess, G.G. (1996). Clarifying the entrepreneurial construct and linking it to performance. Academy of Management Review, 21(1), 135-172.

[11] Miller, D. (1983). The correlates of entrepreneurship in three types of firms. Management Science; 29(7), 770-791.

[12] Covin, J.G. \& Slevin, D.P. (1989). Strategic management of Small Firms in hostile and benign environments. Strategic Management Journal; 10(1), 75-87.

[13] Wiklund, J. \& Shepherd, D. (2005). Entrepreneurial orientation and small business performance: A configuration approach. Journal of Business Venturing, 20, 71-91.

[14] Smart, D.T. \& Conant, J.S. (1994). Entrepreneurial orientation, distinctive marketing competencies and organizational performance. Journal of Applied Business Research, 10:28-38.

[15] Hart, S.L. (1992). An integrative framework for strategy-making processes. Academy of Management Review, 17(2), 327-351.

[16] Akeredolu, A. (1975). The Underdevelopment of Indigenous Entrepreneur in Nigeria. Ibadan: University Press.

[17] Lumpkin, G.T. \&Dess, G. (2001). Linking Two Dimensions of Entrepreneurial Orientation to Firm Performance: The Moderating Role of Environment and Industry Life Cycle. Journal of Business Venturing, 16: 429-451.

[18] Kropp, F., Lindsay, N.J., \& Shoham, A., (2006). Entrepreneurial, market, and learning orientations and international entrepreneurial business venture performance in South African firms, International Marketing Review, 23(5), 504-523.

[19] Miller, D. \& Friesen, P.H., (1984). A Longitudinal Study of the Corporate Life Cycle, Management Science, 30 (10), 1161-118.

[20] Damanpour, F., \&Wischnevsky, J.D. (2006). Research on innovation in organizations: Distinguishing innovation generating from innovation-adopting organizations. Journal of Engineering and Technology Management, 23(4), 269-291.

[21] Mahmood, I.P., \& Rufin, C. (2005). Government's dilemma: The role of government in imitation and innovation. Academy of Management Review, 30 (2), 338-360.

[22] Rauch, A., Wiklund, J., Lumpkin, G.T., \& Frese, M, (2009). Entrepreneurial orientation and business performance: An Assessment of Past Research and Suggestions for the Future. Entrepreneurship Theory and Practice, 33(3), 761-788.

[23] Baker, W.E., \& Sinkula, J.M. (2009). The Complementary Effects of Market Orientation and Entrepreneurial Orientation on Profitability in Small Businesses. Journal of Small Business Management, 47(4), 443464. 
[24] Keh, H.T., Nguyen, T.T.M., \& Ng, H.P. (2007). The effects of entrepreneurial orientation and marketing information on the performance of SMEs. Journal of Business Venturing, 22, 592-611.

[25] Lisboa, A., Skarmeas, D., \& Lages, C. (2011). Entrepreneurial orientation, exploitative and explorative capabilities, and performance outcomes in export markets: A resource-based approach. Industrial Marketing Management, 40(8), 1274-1284.

[26] Yli-Renko, H., \& Janakiraman, R. (2008). How customer portfolio affects new product development in technology-based entrepreneuria firms. Journal of Marketing, 72(5), 131-148.

[27] Sciascia, S., Naldi, L., \& Hunter, E. (2006). Market orientation as determinant of entrepreneurship: an empirical investigation on SMEs. New England Journal of Entrepreneurship, 2, 21-38.

[28] Perez-Luno, A., Wiklund, J. \& Cabrere, R.V. (2011). The dual nature of innovative activity: how entrepreneurial orientation influences innovation generation and adoption. Journal of Business Venturing, 26(5), 555-571.

[29] Dess, G.G. \& Lumpkin, G.T. (2005). The role of entrepreneuria orientation in stimulating effective corporate entrepreneurship. Academy of Management Executive, 19(1), 147-156.

[30] Kerin, R.A., Varadarajan, P.R., \& Peterson, R.A. (1992). First-mover advantage: A synthesis, conceptual framework, and research propositions. Journal of Marketing, 56, 33-52.

[31] Golder, P.N., \& Tellis, G.J. (1993). Pioneer advantage: Marketing logic or marketing legend? Journal of Marketing Research, 30,158-170.

[32] Schwartz, R.G., Teach, R.D., \& Birch, N.J. (2005). A longitudinal study of entrepreneurial firm opportunity recognition and product management strategies: Implications by firm type. International Journal of Entrepreneurial Behavior and Research, 11(4), 315-29.

[33] Kouriloff, M. (2000). Exploring perceptions of a priori barriers to entrepreneurship: A multidisciplinary approach. Entrepreneurship: Theory and Practice. 25(2), 59-67.

[34] Perez-Luno, A., Wiklund, J. \& Cabrere, R.V. (2011). The dual nature of innovative activity: how entrepreneurial orientation influences innovation generation and adoption. Journal of Business Venturing, 26(5), 555-571.

[35] Naldi, L., Nordqvist, M., Sjöberg, K., \&Wiklund, J. (2007) Entrepreneurial orientation, risk taking, and performance in family firms Family Business Review, 20(1), 33-47.

[36] Stewart Jr, W. H., \& Roth, P. L. (2001). Risk propensity differences between entrepreneurs and managers: a meta-analytic review. Journal of Applied Psychology, 86(1), 145-158.

[37] Wisner, (2004). Wisner, J.D. (2003). A structural equation model of supply chain management strategies and firm performance. Journal of Business Logistics, 24(1), 1-26.

[38] Mentzer, J.T., Stank, T.P., \& Esper T.L. (2008). Supply Chain Management and Its Relationship to Logistics, Marketing, Production, and Operations Management. Journal of Business Logistics, 29, 31-46. Doi: 10.1002/J.2158-1592.2008.Tb00067.X.

[39] Green, Jr. K.W., McGaughey, R. \& Casey, K.M. (2006). Does supply chain management strategy mediate the association between market orientation and organizational performance? Supply Chain Management: An International Journal 11(5), 407-414.

[40] Mentzer, J.T. (2007). The role of logistics in new product development Journal of Business Logistics 28(1), 83-110.

[41] Tukamuhabwa, B.R., Eyaa, S., \& Derek, F. (2011). Mediating Variables in the Relationship between Market Orientation and Supply Chain Performance: A Theoretical Approach. InternationalJournal of Business and Social Science, 2 (22).

[42] Salvador, F., Forza, C., Rungtusanatham, M. \& Choi, T.Y. (2001). Supply chain interactions and time-related performances: An operations management perspective, International Journal of Operations \& ProductionManagement, 21(4), 461-475.

[43] Juttner, U., Martin, C. \& Godsell, J. (2010). A strategic framework for integrating marketing and supply chain strategies. The International Journal of Logistics Management, 21(1), 104-1.

[44] Zelbst P.J., Green Jr K.W, Sower, V.E. \& Baker, G. (2010). RFID utilization and information sharing: the impact on supply chain performance. Journal of Business \& Industrial Marketing 25(8), 582589.

[45] Miguel, H., Augusto, R., \& Manuel, S. (2010). Inter-organizational governance, learning and performance in supply chains", Supply Chain Management: An International Journal, 15(2), 101 -114.

[46] Ittner, C.D., Nagar, V. \& Rajan, M.V. (2001). An Empirical Examination of Dynamic Quality-Based Learning Models. Journal of Management Science, 47(4), 563-578.

[47] Casals, F.E. (2011). The SME Co-operation Framework: a Multimethod Secondary Research Approach to SMECollaboration. 2010 International Conference on E-business, Management and Economics IPEDR vol.3. IACSIT Press, Hong Kong.

[48] Kemp, R.G.M., Folkeringa, M., De Jong, J.P.J. \& Wubben, E.F.M. (2003). Innovation and Firm Performance. Zoetermeer, Scales.

[49] Rothwell, R. \& Zegveld, W. (1982). Innovation and the Small and Medium Sized Firm. Pinter: London.

[50] Lumpkin, \& Dess, (2006). The Effect of 'Simplicity' on the StrategyPerformance Relationship: A Note. Journal of Management Studies, 43(7), 1583-1604.

[51] Leko-Simi, M. \& Horvat, J. (2006). Risk Taking Propensity and Export Performance of Croatian Exporters, ManagingGlobal Transitions 4 (4), 313-326.

[52] Panzano, P.C. \& Billings, R.S. (2005). An organizational level test of a partially mediated model of risky decision-making behavior, Accessed on $23^{\text {rd }} \quad$ April 2021 from http://www.dssincorporated.com/Research/RiskyDecision/risky.html.

[53] Gilson, L.L. \& Shalley, C.E. (2004). A Little Creativity Goes a Long Way: An Examination of Teams' Engagement in Creative Processes Journal of Management 30(4), 453-470.

[54] Gupta, \& Govindarajan, (2004). Gupta A. K., Govindarajan V.1984. Business unit strategy, managerial characteristics, and business unit effectiveness at strategy implementation. Academy of Management Journal, 27, 25-41.

[55] Ibrahim, N.M.N, \& Mahmood, R (2016). Mediating role of competitive advantage on the relationship between entrepreneurial orientation and the performance of Small and Medium Enterprises, Medwell Journal of International Business Management; 2444-2452.

[56] Arisi-Nwugballa, E.A, Elom, M.E, \& Onyeizugbe, C.U. (2016). Evaluating the role of entrepreneurial orientation to the performance of Micro, Small and Medium Enterprises in Ebonyi State, Nigeria. International Journal of Academic Research in Accounting, Finance and Management Sciences; 221-230.

[57] Kumarpeli, K.I. \& Semasinghe, D.M. (2015). The Impact of entrepreneurial orientation on the growth of SMEs in Sri Lanka, International Conference on Business, Marketing and Information System Management (BMISM'15); 1-5.

[58] Baker, H.A. Mahmood, R. \& Ismail, N.N.H.N. (2015). Fostering small and medium enterprises through entrepreneurial orientation and strategic improvisation. Mediterranean Journal of Social Sciences; 481-487.

[59] Okeyo, W.O, Gathungu, J.M. \& K'Obonyo, P. (2016). Entrepreneurial orientation, business development services, business environment and performance: A critical literature review. European Scientific Journal, $188-218$.

[60] Amin, M. (2015). The effect of entrepreneurship orientation and learning orientation on SMEs' performance: An SEM-PLS approach, Journal of International Business and Entrepreneurship Development; $215-230$

[61] Kraus, S., Rigtering, J.P.C., Hughes, M. \& Hosman, V. (2012) Entrepreneurial orientation and the business performance of SMEs: A quantitative study from the Netherlands, Review of Managerial Science; 161-182.

[62] Civelek, M. Rahman, A. \&Kozubikova, L. (2016). Entrepreneurial orientation in the segment of Micro-Enterprises: evidence from Czech Republic. International Journal of Entrepreneurial Knowledge; 72-89.

[63] Gupta, A.K., \& Govindarajan, V. (1984), Business unit strategy, managerial characteristics, and business unit effectiveness at strategy implementation, Academy of Management Journal, 27, 25-41.

[64] Hult, G.T.M., \& Ketchen, D.J. (2001). Does market orientation matter? A test of the relationship between positional advantage and performance. Strategic Management Journal, 22(9), 899-906.

[65] Naman, J.L. \& Slevin, D.P. (1993). Entrepreneurship and the concept of fit: A model and empirical tests, Strategic Management Journal, 14(2), 137-53 